GU J Sci, Part C, 7(1): 25-36 (2019)

Gazi Üniversitesi
Fen Bilimleri Dergisi
PART C: TASARIM VE TEKNOLOJI
dergipark.gov.tr/http-gujsc-gazi-edu-tr

\title{
Farklı Metal Çiftlerinin Mekanik Kilitlenme Yöntemi ile Birleştirilmesi
}

\author{
Serdar MERCAN ${ }^{1}$ \\ ${ }^{I}$ Cumhuriyet Üniversitesi, Teknoloji Fakültesi, Mekatronik Mühendisliği Bölümü, SIVAS
}

\section{Makale Bilgisi}

Başvuru: 27/06/2018

Düzeltme: 11/11/2018

Kabul: 26/11/2018

\section{$\underline{\text { Anahtar Kelimeler }}$ \\ Mekanik kilitleme yöntemi Bi-metal \\ Metalurjik özellikler \\ Mekanik özellikler \\ Plastik şekil verme}

\section{Keywords}

Mechanical locking method

Bi-metal

Metallurgical properties

Mechanical properties

Plastic forming

\begin{abstract}
$\ddot{O} z$
Malzemeler sökülebilen ve sökülemeyen birleștirme yöntemleri kullanılarak birleştirilirler. Ancak farklı malzeme türlerinin birleştirilmesi söz konusu olduğunda birçok birleştirme yönteminin kullanılması güç ve problemlidir. $\mathrm{Bu}$ nedenle farklı malzeme türlerinin birleştirilmesinde mekanik kilitleme yöntemi kullanılarak uygulamada karşılaşılan bazı problemlerin önüne geçilebilecektir. Yöntem ile seramikler ile metaller, demir esaslı malzemeler ile demir dişı metaller ve diğer malzeme türleri birbirleri ile birleştirilebilir. Bu çalışma kapsamında farklı kimyasal bileşime sahip AISI 1040 ve AA 1050 metal çiftleri mekanik kilitleme ile birleştirilerek yöntemin uygulanabilirliği araştırılmıştır. Birleştirilen numunelerin mekanik analizleri yapılmış ve mikro yapı incelemeleri tamamlanmıştır. Yapılan çalışma sonucunda farklı malzeme çiftlerinin mekanik kilitleme yöntemi ile başarılı bir şekilde birleştirileceği görülmüştür.
\end{abstract}

\section{Joining of Dissimilar Metal Pairs by Mechanical Locking Method}

\begin{abstract}
The materials are assembled using assembly and disassembly methods. However, when the joining of dissimilar material types comes into question, it is difficult and problematic to use many joining methods. For this reason, some problems encountered in the application can be prevented by using the mechanical locking method for joining of dissimilar material types. Ceramics and metals, ferrous materials, non-ferrous metals and other material types can be joined with each other by using the method. In this study, the applicability of the method was investigated by joining AISI 1040 and AA 1050 metal pairs with different chemical compositions via mechanical locking method. Mechanical analyses of the joined samples were carried out and microstructure studies were completed. As a result of this study, it was observed that different material pairs will be successfully joined by using the mechanical locking method.
\end{abstract}

\section{GİRIŞ (INTRODUCTION)}

Günümüzde farklı metal çiftleri birleştirilerek, birçok endüstriyel uygulamada yaygın olarak kullanılmaktadır. Bu uygulamalara; dış yüzeyinin sert, iç kısımlar ve bağlantı bölgesinde tokluk değerinin yüksek olması gereken bimetalik çekiçler, korosif ve abrasif etkileri minimize etmek amacı ile yapılan bimetalik kovanlar, termostatik esaslara dayalı olarak çalışan bimetal plakaların kullanıldığı kondenstoplar ve bimetal kablo pabuçları gibi birçok örnek gösterilebilir. Bununla birlikte endüstrideki enerji ve çevre sorunlarının, malzeme seçimi ve birleştirme tekniklerinin geliştirilmesi üzerinde güçlü etkisi devam etmektedir [1].

Endüstriyel uygulamalarda birçok alanda malzemelerin birleştirilmesinde kaynak yöntemi kullanılır. Ancak malzemeler arasında kimyasal uyumsuzluk sözkonusu ise bu malzemelerin kaynak yöntemi ile birleştirilmesi neredeyse imkânsızdır [2]. Bununla birlikte kaynak hataları nedeni ile meydana gelen yüksek gerilmeler, kaynaklı bağlantıların hasar sürecinde olumsuz rol oynamaktadır [3]. Bu nedenle bu çalışma kapsamında; farklı kimyasal bileşime sahip malzeme türlerinin, yeni bir imalat yöntemi olan mekanik kilitleme ile birleştirilebilirliği incelenmiştir. Böylece bimetalik uygulamalar ile, ihtiyaca uygun farklı malzeme çiftlerinin birlikte kullanılabilmesi ve malzeme üretim maliyetlerinin düşürülmesi hedeflenmiştir. Mekanik kilitleme yöntemine ait TR201503256B no' lu patent işlemleri 2017 yılında tamamlanmıştır [4]. 
Metal imalat tekniklerinde 1sı kullanılması yaygın bir uygulamadır. Bunlar arasında döküm, kaynak, kesme, sıcak şekillendirme, dövme veya toz metalurjisi gibi metal imalat teknikleri bulunmaktadır. Belirli bir 1sıl çevrim, başarılı üretim ve ürün kalitesi için büyük önem taşımaktadır [5]. Bu çalışma kapsamında seçilen mekanik kilitleme yönteminde, sürtünmeden elde edilen 1s1 etkisi farklı malzeme türlerinin birleştirilmesinde kullanılmıştır. Mekanik kilitleme yöntemi ile demir esaslı malzemeler demir dışı metaller, kompozit malzemeler ve seramik malzemeler gibi birçok malzeme türü birbirleri ile birleştirilebilir. Bu amaçla; bu yöntem kullanılarak birleştirilecek iki parçadan, biri erkek parça diğeri dişi kalıp parçası olarak tasarlanır. Birleştirilecek iki malzeme türü arasında ergime 1sısı yüksek olan parça, kalıp parçası olarak seçilir. Kalıp parçasının üzerine farklı ölçülerde konik kanal veya T kanal açılır. Erkek parça olarak hazırlanan malzemenin plastik şekil değiştirme özelliğine sahip bir malzemeden seçilmesi gerekmektedir [4]. Parçaların ön hazırlıkları tamamlanarak, erkek parçanın kalıp parçası üzerinde açılan kanal içi ara yüzeyinde dönerek sürtünmesini ve aralarında eksenel basınç oluşmasını sağlayacak bir sistem tasarlanır. Bu sistem içinde üretilen mekanik enerjinin termal enerjiye dönüştürülmesiyle elde edilen 1sıdan yararlanılır. Sürtünme hareketi, sürtünme kaynak yönteminde olduğu gibi plastik deformasyon sıcaklığına ulaşıncaya kadar devam eder. Parçaların sürtünmekte olan yüzeylerinde, 1sı açığa çıkar ve basınç etkisi ile erkek parça yığılmaya başlar. Yığılan malzemenin kalıp şeklini alması sağlanır. Bağlantı; ara yüzeyde oluşturulan sürtünme ve açığa çıkan ısıya bağlı meydana gelen bir kaynaklı bağlantı olmayıp, kalıp parçası üzerine açılan T kanal veya konik kanal yardımı ile gerçekleştirilir. Erkek parçanın kalıp parçasının şeklini alması sonucunda sürtünme hareketi durdurulur [4]. Sürtünme hareketinin ani olarak durdurulması ara yüzeylerde meydana gelebilecek olası bölgesel kaynakların bozulmasını engeller. Mekanik kilitleme yönteminin uygulanmasında klasik sürtünme kaynak tezgâhları kullanılabilir. Mekanik kilitleme yönteminde, sürtünme kaynağında olduğu gibi malzeme çiftlerinde atomik seviyede bir birleştirme olmaz. $\mathrm{Bu}$ nedenle yöntem parametreleri, sürtünme kaynak parametrelerinden bağımsız olarak değerlendirilir. Ancak kullanılacak parametreler isim olarak benzerlik göstermektedir. Sürtünme kaynak yönteminde metalurjik bir bağ oluşturmak amacı ile belirlenen parametreler, mekanik kilitleme yönteminde erkek parçanın mekanik özelliklerini kaybetmeden hamurumsu hale getirilmesi amaciyla belirlenir. $\mathrm{Bu}$ parametreler sürtünme süresi, devir sayısı ve sürtünme basıncıdır. Diğer taraftan bağlantı kalitesi üzerinde önemli etkisi bulunacağı düşünülen, kalıp parçası kanal derinliği, bağlantı açısı, kanal köşe radyuslarının malzeme özelliklerine uygun olarak belirlenmesi gerekir.

Yöntemde ihtiyaç duyulan enerji sürtünme yolu ile elde edilmektedir. Ergime sıcaklığg altındaki bir sıcaklıkta malzemelere eksenel bir basıncın uygulanması gerekmektedir. Basıncın etkisi ile oluşturulan plastik deformasyon yardımı ve kanal şekline bağlı olarak sökülemeyen mekanik bir birleşme sağlanmaktadır [4]. Yöntem ergime sıcaklıkları arasındaki farkın büyük olduğu farklı malzeme türlerinin birleştirilmesinde de sorunsuz bir şekilde kullanılabilmektedir. Yöntemin dezavantajı ise birleştirme işlemi öncesinde parçaların talaşlı imalat gibi yöntemler ile ön hazırlı̆̆ının yapılması gerekmektedir. Ayrıca parça boyutlarının artması ile birleştirme işlemi için daha büyük ve güçlü tezgâhlara ihtiyaç duyulmaktadır. Parça boyutlarının daha küçük olması durumunda ise talaşlı imalat işlemleri zorlaşmaktadır.

Konu ile alakalı yapılan çalışmalarda; Cong Wang ve arkadaşları hızlı soğutma oranı ve büyük sıcaklık gradyanı ile homojen olmayan plastik deformasyonun malzemeler üzerindeki etkilerini araştırmıştır. Kalıntı gerilmelerin kalınlık açısından tekdüze olmadığını ve yüzeyde sıkıştıııcı, daha sonra derinlikle birlikte mutlak büyüklükte arttığını ve merkezde gerilme meydana getirdiğini bildirmiştir. Ekstrüzyon yönünde küçük akış gerilmesinin kalıntı gerilmeleri azalttığını tespit etmiştir [6]. Robinson vd. 1sıl işlem görmüş alüminyum alaşımlarında alaşım bileşiminin artık gerilmeler üzerindeki etkisini incelemişler ve homojen olmayan plastik akışın malzemeler üzerinde kalıntı gerilmeler meydana getirdiğini bunun mekanik özellikleri olumsuz etkilediğini bildirmiştir [7]. Zheng ve diğerleri; $\mathrm{Mg}-3 \mathrm{Al}-\mathrm{Zn}$ alaşımlı levhaların mekanik özelliklerini iyileştirmek için uygun bir alaşım ve haddeleme yöntemi araştırmıştır. Sıcak haddelenmiş alaşımların ön-ekstrüzyona tabi tutulduğunu ve Al-Si alaşımlama ilavesinin farklı bir bimodal dağ 1 lım karakteristiği ve optimal tane arıtımı sergilediğini bildirmiştir [8]. Xue tarafindan Al esaslı negatif poisson oranına sahip bir malzemeyi 3-D ve döküm yöntemi ile üreterek mekanik davranışları araştırılmış ve ek olarak dikme yapılmasının veya dikmelerin giriş açısının uzunluğunun arttırılmasının sıkıştırma mukavemetini azalttığını poisson oranını ise arttırdığını bildirmiştir [9]. Kai, ekstrüze edilmiş yuvarlak profil alüminyum alaşım için deformasyon dokusu ve onun kalınlık heterojenitesi, elektron geri-saç1lım difraksiyon tekniği (EBSD) ile deneysel olarak ölçmüş ve FEM akış simülasyonu ve kristal plastisite simülasyonları birleştirerek sayısal olarak modellemiştir [10]. Daha önce yapılan çalışmalar incelendiğinde; 
mekanik kilitleme yönteminin günümüz imalat yöntemleri içinde kullanılmadığı görülmüş olup bu bakımdan çalışmanın literatüre önemli katkılar sağlayacağı düşünülmektedir.

$\mathrm{Bu}$ çalışmanın ana amacı, farklı kimyasal ve mekanik özelliklere sahip malzeme türlerinin mekanik kilitleme yöntemi kullanılarak birleştirilmesini incelemektir. Bu amaçla, birleştirilen AISI1040 ve AA 1050 malzeme çifti üzerinde bağlantı mikro yapısı ve mekanik özellikleri incelenmiştir. Elde edilen sonuçlar 1şığında mekanik kilitleme yönteminin diğer imalat yöntemleri ile birleştirilemeyen malzeme türlerinin birleştirilmesinde kullanılabileceği tespit edilmiştir.

\section{DENEYSEL ÇALIŞMA (EXPERIMENTAL STUDY)}

Mekanik kilitleme yöntemi kullanılarak birleştirilecek numunelere şematik görünüşü Şekil 1' de verilmiştir. Erkek parça kalıp parçası üzerindeki kanal içinde gerekli olan sürtünme hareketini sağlayacak şekilde ve plastik şekil değiştirme sonucunda kanal içini doldurabilecek boyutlarda imal edilmiştir.
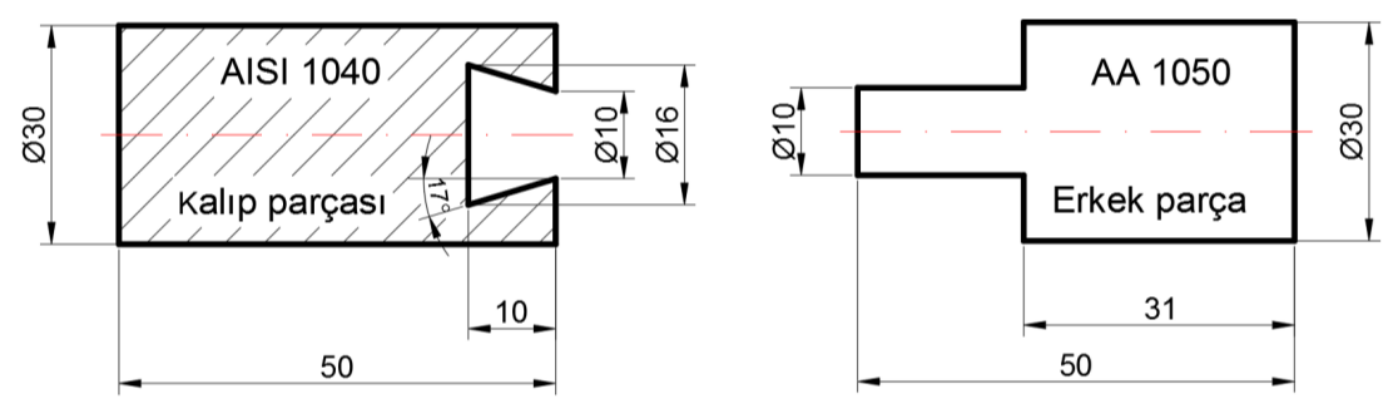

Şekil 1. Mekanik kilitleme yönteminde kullanılan numune boyutları (mm)

Bu çalışmada; numuneler sürtünme süresi boyunca $40 \mathrm{MPa}$ sabit basınç altında ve $2500 \mathrm{~min}^{-1}$ dönme hızı seçilerek hazırlanmıştır. Sürtünme işlemi erkek parça ve kalıp parça alın alına birleştirilinceye kadar devam ettirilmiştir (6 s). Birleştirilen numunelere ait spektral analiz sonucu elde edilen kimyasal kompozisyon Tablo 1' de, verilmiştir.

Tablo 1. AISI 1040 ve Al 1050 malzeme çiftlerine ait kimyasal kompozisyon (\% Ăgırlıkça)

\begin{tabular}{|l|l|l|l|l|l|l|l|l|}
\hline & C & Mn & Si & Mg & Cu & $\begin{array}{l}\text { S } \\
(\mathbf{m a x})\end{array}$ & Al & Fe \\
\hline AISI 1040 & 0,42 & 0,55 & 0,30 & --- & --- & 0,035 & --- & Balans \\
\hline AA 1050 & --- & 0,002 & 0,25 & 0,05 & 0,05 & --- & Balans & 0,4 \\
\hline
\end{tabular}

Birleştirilen numunelerin ara yüzeylerindeki temas hattı boyunca Şekil 2' de gösterildiği gibi üç farklı doğrultuda, matris malzemesine kadar mikro sertlik değerleri ölçülmüştür. Vickers sertlik ölçümleri $10 \mathrm{~N}$ yük altında ve $0,5 \mathrm{~mm}$ aralıklarda ve $15 \mathrm{~s}$ bekleme süresi kullanılarak yapılmıştır.

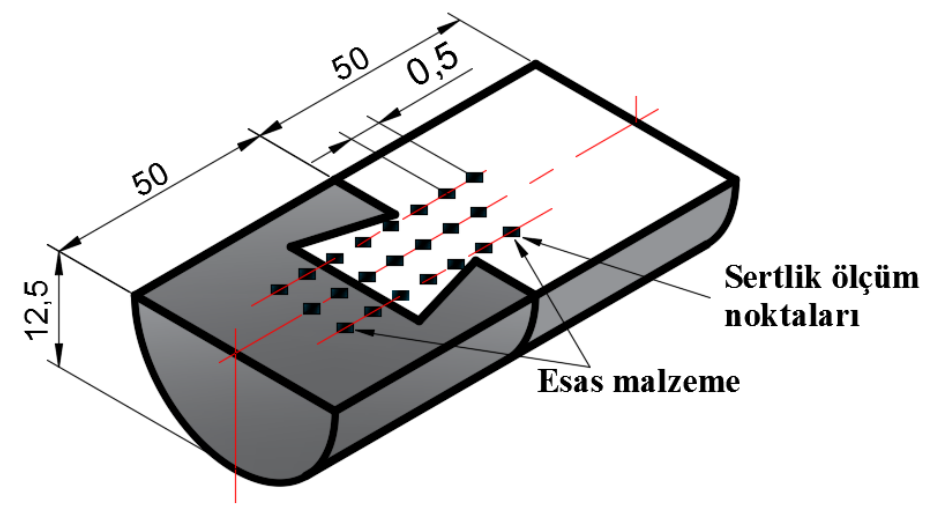

Şekil 2. Mikro sertlik ölçüm bölgeleri (mm) 
Çekme deney numuneleri; TS EN ISO 6892-1/Mart 2011 standardına uygun olarak hazırlanmıştır. Şekil 3' te çekme deney numunesine ait şematik görüntüsü gösterilmiştir.

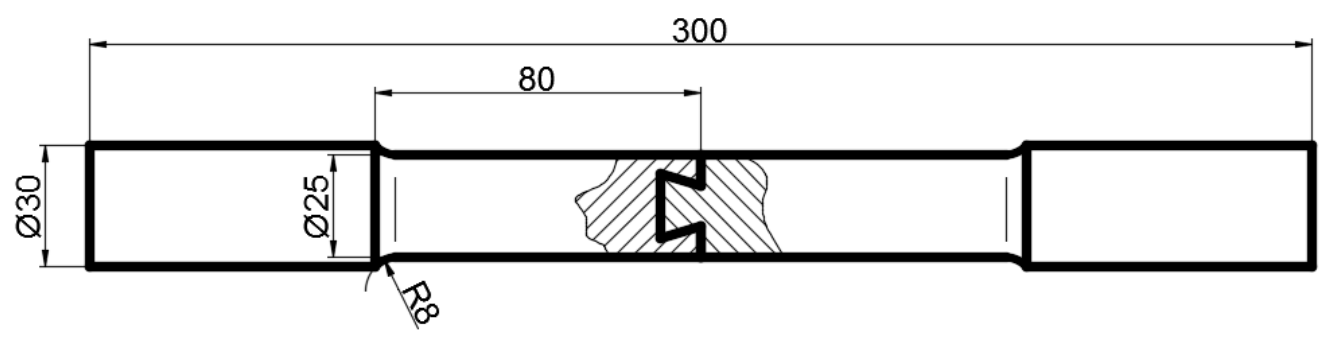

Şekil 3. Çekme deney numunesi şematik görüntüsü

\section{DENEY SONUÇLARI (EXPERIMENTAL RESULTS)}

AISI 1040 ve AA 1050 gerek ergime sıcaklıklarındaki fark, gerekse kimyasal farklılıkları nedeni ile kaynak yöntemleri ile birleştirilmesi mümkün değildir. Mekanik kilitleme yöntemi kullanılarak birleştirilen numunenin makro görüntüsü Şekil 4' te gösterilmiştir. Isı iletim katsayısının düşük olması ve sürtünme ara yüzeyinin çelik malzeme içinde kalması nedeni ile AISI 1040 malzeme üzerinde 1sıdan etkilenen bölge (IEB) net olarak görülmektedir. IEB' nin sürtünme ara yüzey doğrultusunda arttı̆̆ 1 parçanın diğer kısımlarında ise daha az olduğu görülmektedir. AA 1050 alaşımlı malzemelerin 1s1 iletim katsayısının çeliklere kıyasla daha yüksek olması nedeni ile sürtünme ara yüzeyinde meydana gelen 1sı Al malzeme tarafından hızla uzaklaştırılmıştır. Ayrıca AA 1050 malzemenin görülebilen dış yüzeyinin sürtünme bölgesinden uzak olması nedeni ile AA 1050 malzeme tarafında 1sıdan etkilenen bölgeler görülmemiştir.

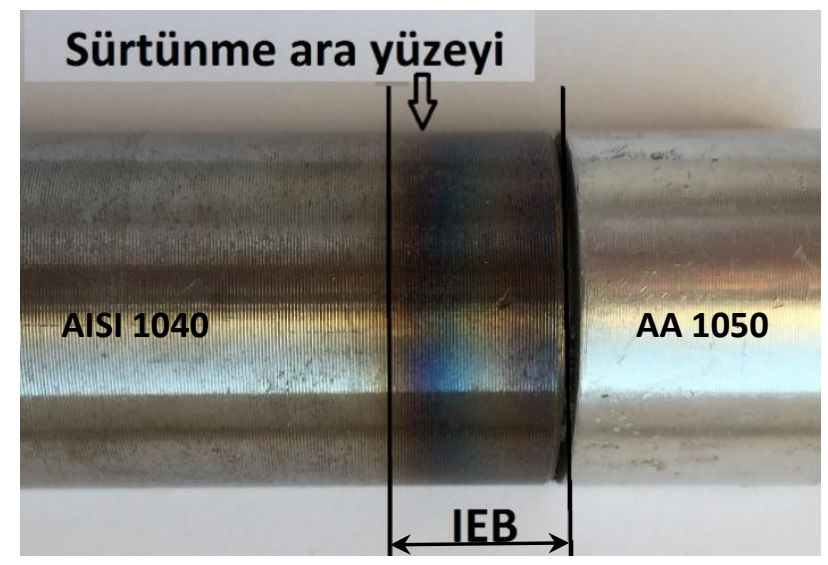

Şekil 4. Birleştirilen numunelere ait makro fotoğraf

Al 1sıl genleşme katsayısı çeliklere göre yaklaşık iki kat daha yüksektir (Isıl genleşme katsayıları -oda sıcaklığında $\alpha_{1 \mathrm{Al}}=23,6 \cdot 10^{-6} 1 / \mathrm{C}^{\circ}, \alpha_{1 \mathrm{Fe}}=12 \cdot 10^{-6} 1 / \mathrm{C}^{\circ}$ ) [11]. Ancak Al 1sı iletim katsayısının çeliklere göre yaklaşık dört kat yüksek olması nedeni ile Al üzerindeki 1sı hızla çelik tarafına iletilerek genleşmeye bağlı problemlerin önüne geçilmiş ve birleştirilen parçaların alın yüzeylerinin tam temas etmesi sağlanmıştır $\left(\mathrm{k}_{\mathrm{Al}}=247 \mathrm{~W} / \mathrm{m} . \mathrm{K}, \mathrm{k}_{\mathrm{Fe}}=52 \mathrm{~W} / \mathrm{m} . \mathrm{K}\right)$ [11]. Isıl genleşme katsayısı çeliğin yaklaşı iki katı olan alüminyumun kalıp parçasının içinde tam olarak şekil alması ve soğuma sonrası boşluk oluşmasını engellemek amacıyla yeterli sürtünme basıncının uygulanması gerekmektedir. Al malzemenin sürtünme basınc1 etkisi ile plastik deformasyon sonucunda boşluksuz bir şekilde kalıbın şeklini aldığ 1 ve kalıbın içini doldurduğu Şekil 5' te verilen SEM görüntüsü ve Şekil 6' da verilen ara yüzey makro görüntüsünde gösterilmiştir. 


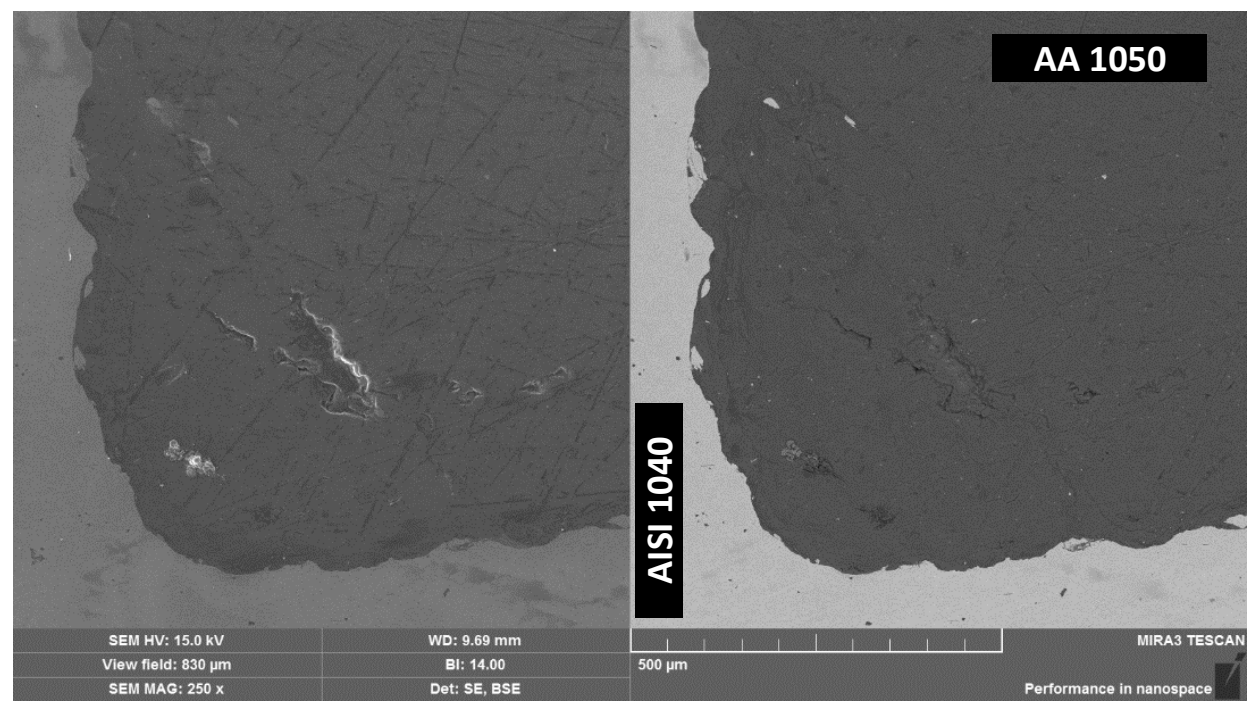

Şekil 5. Birleştirilen numune SEM görüntüsü

AISI 1040 ve AA 1050 malzeme çifti farklı fiziksel ve mekanik özelliklere sahip olmaları nedeni ile farklı plastik deformasyon miktarları sergilerler [12]. Çeliklerin mekanik özellikleri alüminyuma göre daha yüksektir. Bu nedenle bağlantı esnasında meydana gelen deformasyon AA 1050 tarafinda meydana gelmiştir. AISI 1040 çelik tarafında hemen hemen hiç deformasyon meydana gelmediği tespit edilmiştir (Şekil 6).

Şekil 6' de verilen makro görüntüde birleşme ara yüzeylerine yakın bölgelerde dairesel alan içinde gösterilen kısımlarda AA 1050 tarafında porozite oluştuğu tespit edilmiştir. Al ve Mg gibi kimyasal olarak aktif malzemelerin üretiminde, inklüzyon, büzülme, gözeneklilik gibi metalurjik defektlerin meydana geleceği bilinmektedir [9]. Bağlantı ara yüzeyine yakın bölgelerde oluşan bu porozitenin yeterli 1sı ve basıncın kullanılmamış olmasından kaynaklandığı düşünülmektedir. Basıncın yetersiz olması metal akışını olumsuz etkilemektedir. Benzer bir durum farklı bir birleştirme yöntemi olan sürtünme karıştırma kaynağında daha önce tanımlanmıştır. Sürtünme karıştırma kaynağında yetersiz metal akışının ve düşük sıcaklıkların karıştırma bölgesinde porozite oluşumuna neden olduğu görülmüştür [13]. 


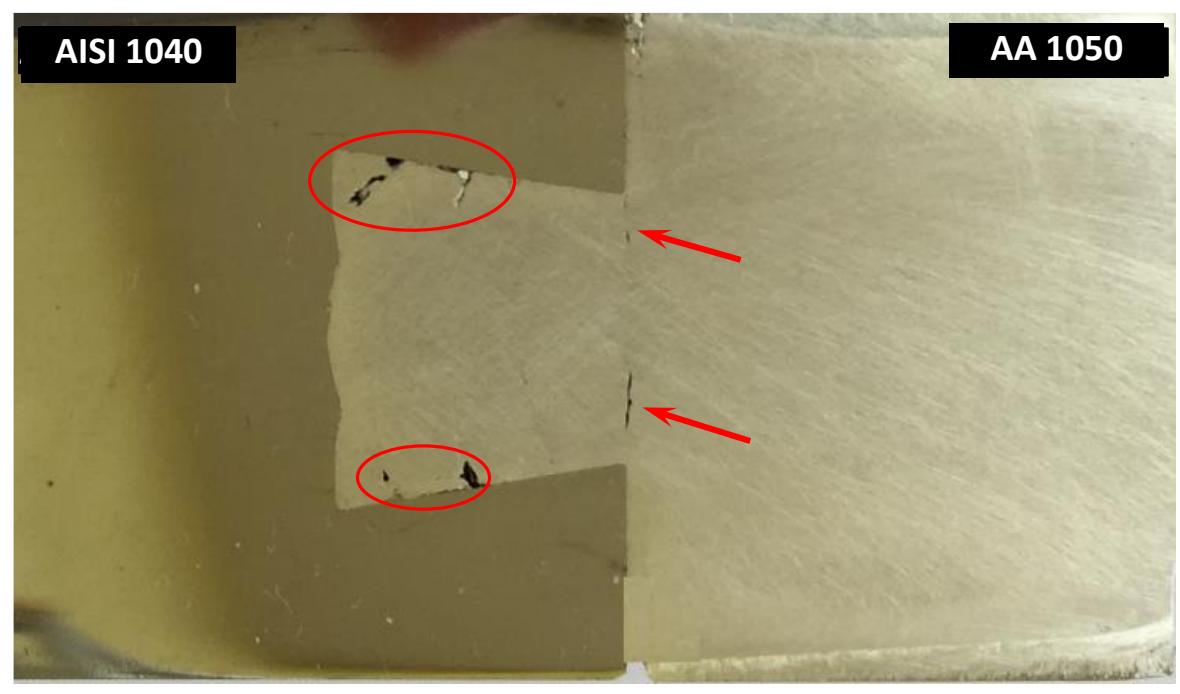

Şekil 6. Birleştirilen numune makro fotoğrafi

Bununla birlikte Şekil 6' da oklarla gösterilen kısımlarda AA 1050 malzeme üzerinde çatlaklar gözlemlenmiştir. Çatlak oluşumunun ısınan AA 1050 malzemede kesitin daralmaya başladığı kısımda meydana geldiği görülmektedir. $\mathrm{Bu}$ durumun; daha önce yapılan çalışmalarda belirtildiği gibi alüminyumun hacimce daralmasından kaynaklanan çekme boşlukları olarak meydana geldiği düşünülmektedir [14].

AA 1050 tarafında, birleşme bölgesine yakın kısımlarda basınç etkisi ile yönlenen tanelerin hızlı soğuması sonucunda mikro çatlaklara neden olduğu Şekil 7' de verilen SEM görüntüleri ile gösterilmiştir. Mikro çatlakların bağlantı sınır bölgesine yakın oldukları ve uzun bir hat boyunca ilerledikleri tespit edilmiştir. Mikro çatlaklar hızlı plastik deformasyonun meydana getirdiği çekme etkisi ve düzensiz soğuma nedeni ile oluşmuştur [15]. Söz konusu mikro çatlak oluşumunun katılaşma sırasında yetersiz besleme nedeni ile oluşan çekme, sıvı metal içerisinde çözünmüş olan fazla hidrojen veya her ikisinin etkisi ile meydana geldiği bilinmektedir. Ancak gaz porozitelerinin yuvarlak ve düzenli görünüme sahip olduğu belirtilmiştir [16]. Bu nedenle oluşan porozite şeklinin gaz porozitesi olmadığı ve literatürde bildirildiği gibi çekmeye bağlı olarak meydana gelen porozite şekline benzemesi olması bu sonucu doğrular niteliktedir. 

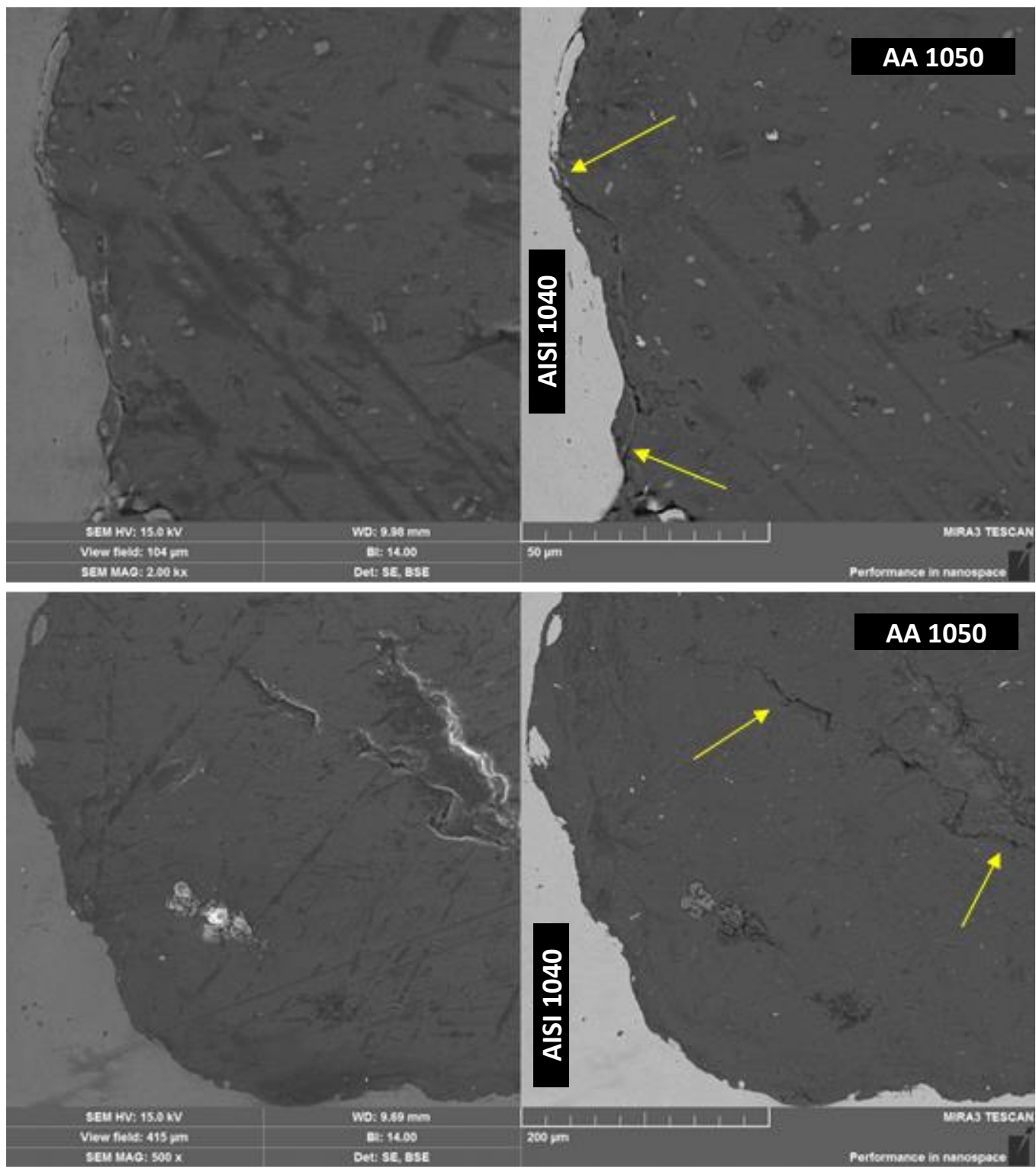

Şekil 7. Çatlak oluşumunun SEM görüntüsü

Atomların materyaller arasında dağılması için yeterli 1sı, difüzyon zamanı ve basıncın gerekli olduğu iyi bilinmektedir [17]. Yapılan bu çalışmada ise numuneler arasında gerçekleşen difüzyon miktarının çok az olduğu Şekil 8' de verilen SEM görüntülerinde açıkça görülmektedir. Şekil 8 incelendiğinde temas yüzeylerine çok yakın bölgelerde bile difüzyonun yetersiz olduğu görülmüşsür. Bu nedenle mekanik kilitleme yöntemi kullanılarak birleştirilen AISI 1040 ve AA 1050 malzeme arasında difüzyon için sıcaklık, basınç ve sürenin yeterli olmadığı düşünülmektedir [18]. Difüzyon süresi ve difüzyon miktarı çalışma parametrelerine bağlıdır ve sıcaklık ile bağlanma tipine bağlı olarak değiştiği bilinmektedir $[19,20]$. Bu nedenle mekanik kilitleme yöntemi kullanılarak birleştirilecek malzeme çiftleri arasındaki difüzyon miktarının parametrelere bağlı olarak arttırılabileceği düşünülmektedir. 

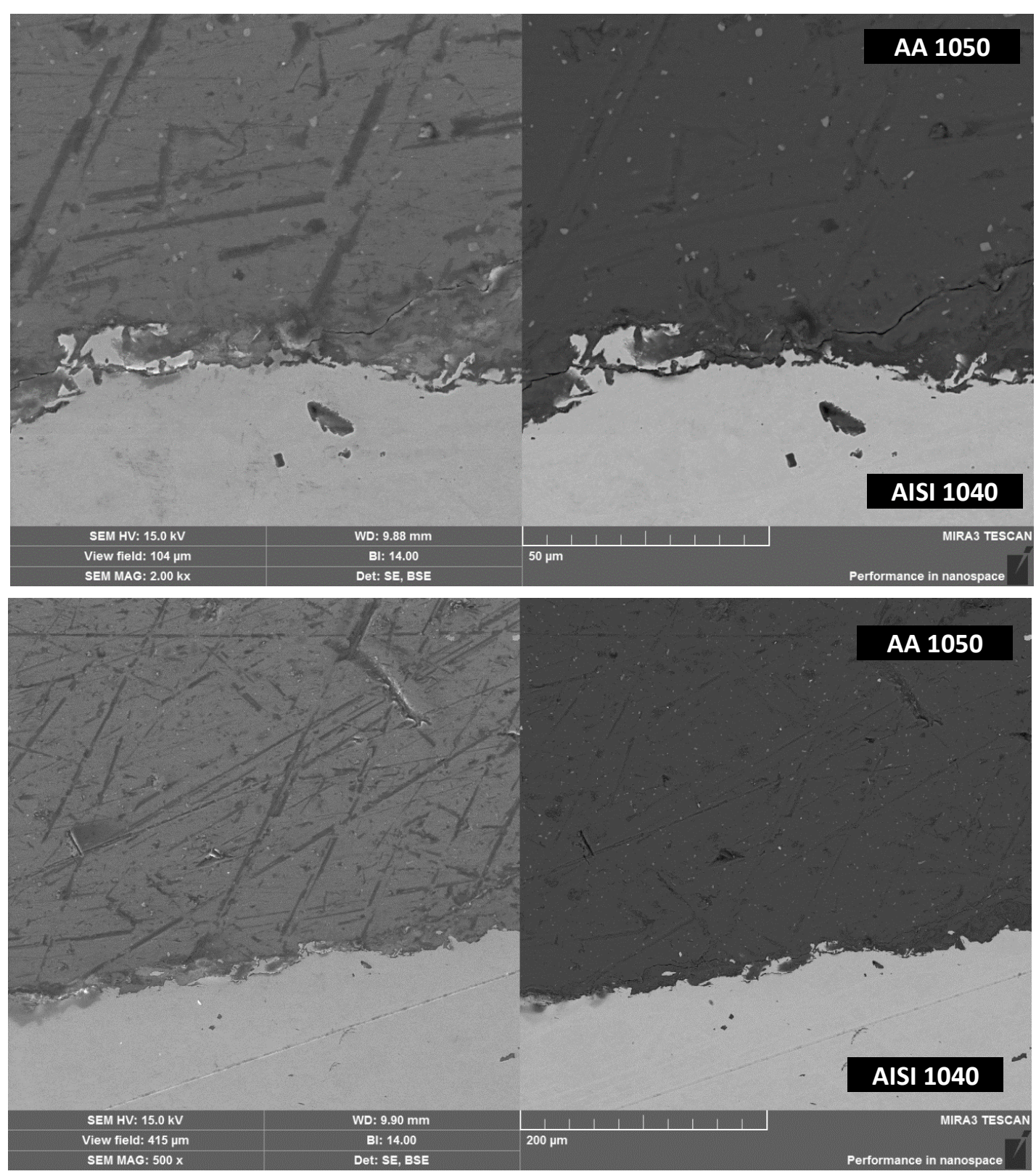

Şekil 8. Birleşme ara yüzeyi SEM görüntüsü

Sinterlenmiş metallerin birleştirilmesinde partikül yüzeyinde oluşan oksit filmleri, atomik difüzyonu yani bağlanmayı engelleyen bir olumsuzluktur. Basıncın yüksek tutulması yüzeyde olabilecek oksit filmlerinin sıcak presleme sürecinde 1sı ve yük tesiri altında kırılarak difüzyonu engelleyici etkileri azaltacağı bilinmektedir [21]. Bu çalışmada parça ara yüzeyinden alınan analiz sonuçlarına göre belli oranda oksitlenmenin meydana geldiği görülmüştür. Ara yüzeyde oluşan oksit tabakasının yeterli isı ve basınç yardımı ile kırılabileceği ve difüzyon miktarının belirtildiği gibi arttırılabileceği görülmüştür.

Diğer taraftan intermetalik oluşumunun $\mathrm{Fe}$ ve $\mathrm{Al}$ arasında difüzyon oluşumunu engellediği bilinmektedir [21]. Şekil 9' da verilen SEM görüntüsünde ara yüzeyde oluşan intermetalik difüzyonun meydana gelmesi için gerekli 1sı enerjisinin ve sürenin sağlanamadığı görülmektedir. Sonuç olarak bu çalışma kapsamında malzemelerin birbirine sadece mekanik olarak bağlandıkları, taneler arası difüzyonun olmadığı tespit edilmiştir. 


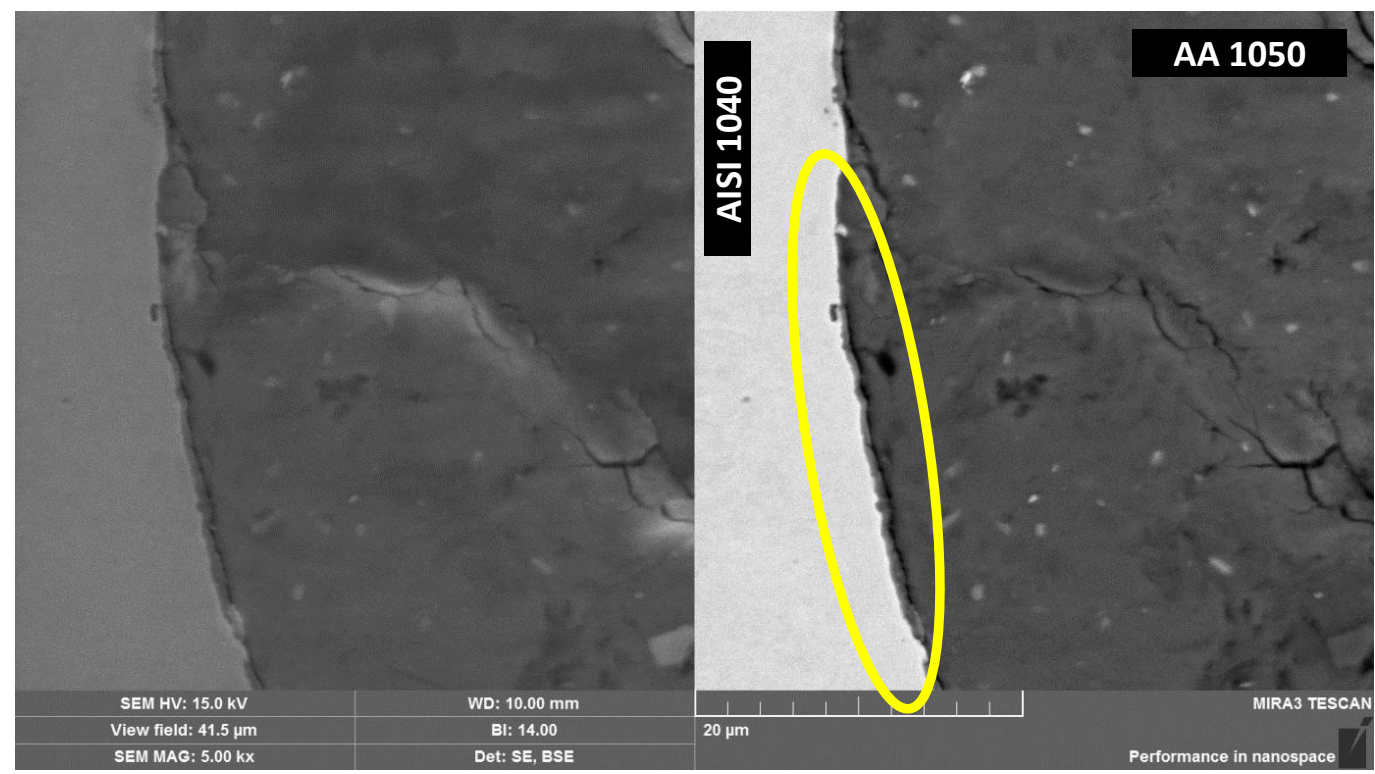

Şekil 9. Băglantı ara yüzeyinde oluşan intermetalik yapı

AISI 1040 malzeme ortalama sertlik değeri 226 HV AA 1050 malzeme ortalama sertlik değeri 30 HV olarak ölçülmüsstür. Yapılan sertlik ölçümleri birleşme ara yüzeyinden her iki tarafa doğru, birbirine paralel üç farklı doğrultuda (Şekil 10 a,b,c doğrultularında) yapılmış, sürtünme yüzeyi ve yan yüzeylerde meydana gelen mikro sertlik değerleri tespit edilmiştir. Üç doğrultudan elde edilen mikro sertlik profilleri birbirine benzerdir (Şekil 10). AISI 1040 tarafinda ara yüzeye yakın bölgelerde sertlik değerinin oluşan sıcaklık nedeni ile azalarak yaklaşık $132 \mathrm{HV}$ ye kadar düştüğü görülmüştür. AA 1050 tarafinda ise sertlik değeri ara yüzey ve bağlantı boyunca önemli bir değişiklik göstermemiştir. AA 1050 alaşımı tarafında yeniden kristalleşmiş bölge ile matrisin sertliklerinin yaklaşık aynı olduğu görülmüştür. Ancak Şekil 10 üzerinde " $x$ " ile gösterilen köşe kısımlarda sertlik değerlerinin yaklaşı $2 \mathrm{~mm}$ mesafede, bir miktar arttığ 1 tespit edilmiştir. Bu durumun plastik şekil değişimine bağlı olarak ortaya çıktığı tespit edilmiştir [22].

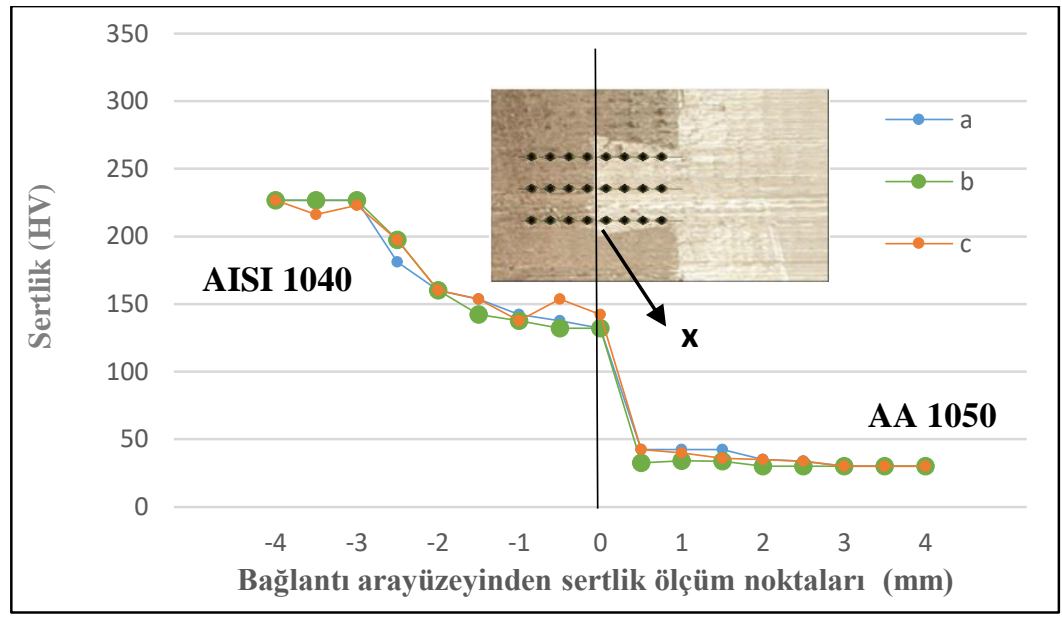

Şekil 10. Bağlantı ara yüzeyinde meydana gelen mikro sertlik dağılımları

AISI 1040 ve AA 1050 ana malzemeler ve birleştirilen numunelere ait çekme deney sonuçları Şekil 11' de standart sapma değerleri ile birlikte gösterilmiştir. Deney sonuçları farklı malzeme çiftleri kullanılarak mekanik kilitleme yöntemi ile ana matrisin mekanik özelliklerine sahip bağlantılar elde edilebileceğini göstermektedir. Farklı malzeme türlerinin birleștirilmesinde kaynaklı numunelerin mukavemeti ile orijinal malzemelerin mukavemeti kıyaslandığında, kaynaklı numunelerin mukavemetinin daha düşük olduğu bilinmektedir. Bu çalışma kapsamında mekanik kilitleme yöntemi kullanılarak birleştirilen farklı metal çiftlerinin bağlantı mukavemetinin birleştirilen AA 1050 malzeme mukavemetine çok yakın olduğu tespit edilmiştir. 


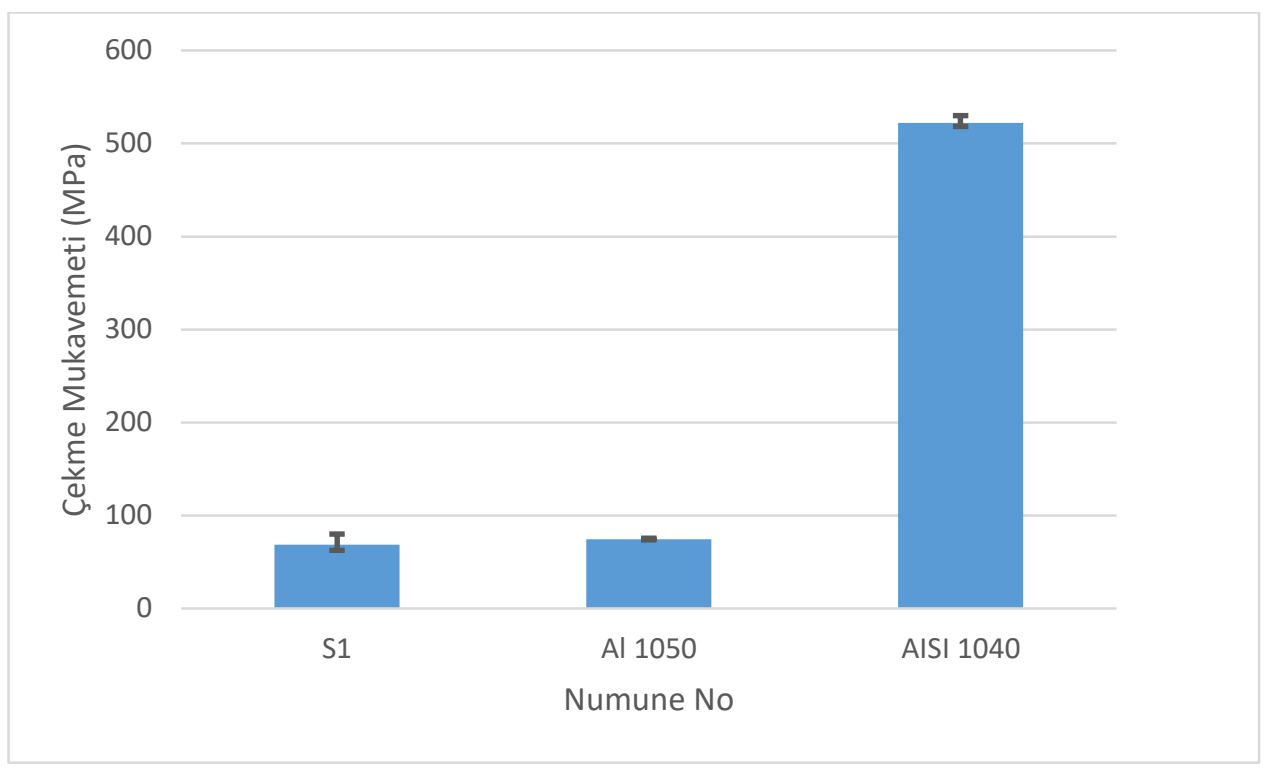

Şekil 11. Çekme deney sonuçları

AA 1050 birleştirilme sürecinde yüksek oranda ve düzensiz oluşan bir plastik deformasyona maruz kalmıştır. Çelik ve Al arasındaki ısı iletim katsayısı arasındaki büyük farklılıklar düzensiz bir soğumanın meydana gelmesine neden olmuştur. Hızlı soğuma oranı ve büyük sıcaklık gradyanı homojen olmayan plastik deformasyon ve bunlara bağlı artan kalıntı gerilmeler meydana gelmiştir [6]. Ayrıca seçilen parametreler nedeni ile her iki malzeme tarafinda önemli miktarda difüzyonun meydana gelmediği ve gözeneklerin oluştuğu görülmüştür. Yukarda yazılan bu sebepler bağlantı mukavemetini azaltan ana etkenler olarak ortaya çıkmıştır.

Şekil 12' de çekme deneyi sonucunda kopan numunelere ait makro görüntü verilmiştir. Çekme deneyi sonucunda AA 1050 malzemenin kesitin daraldığı noktadan kopmadığı görülmüştür. AA 1050 tarafında malzemenin kalıp parçası içinden yırtılarak ayrıldığı görülmüştür.

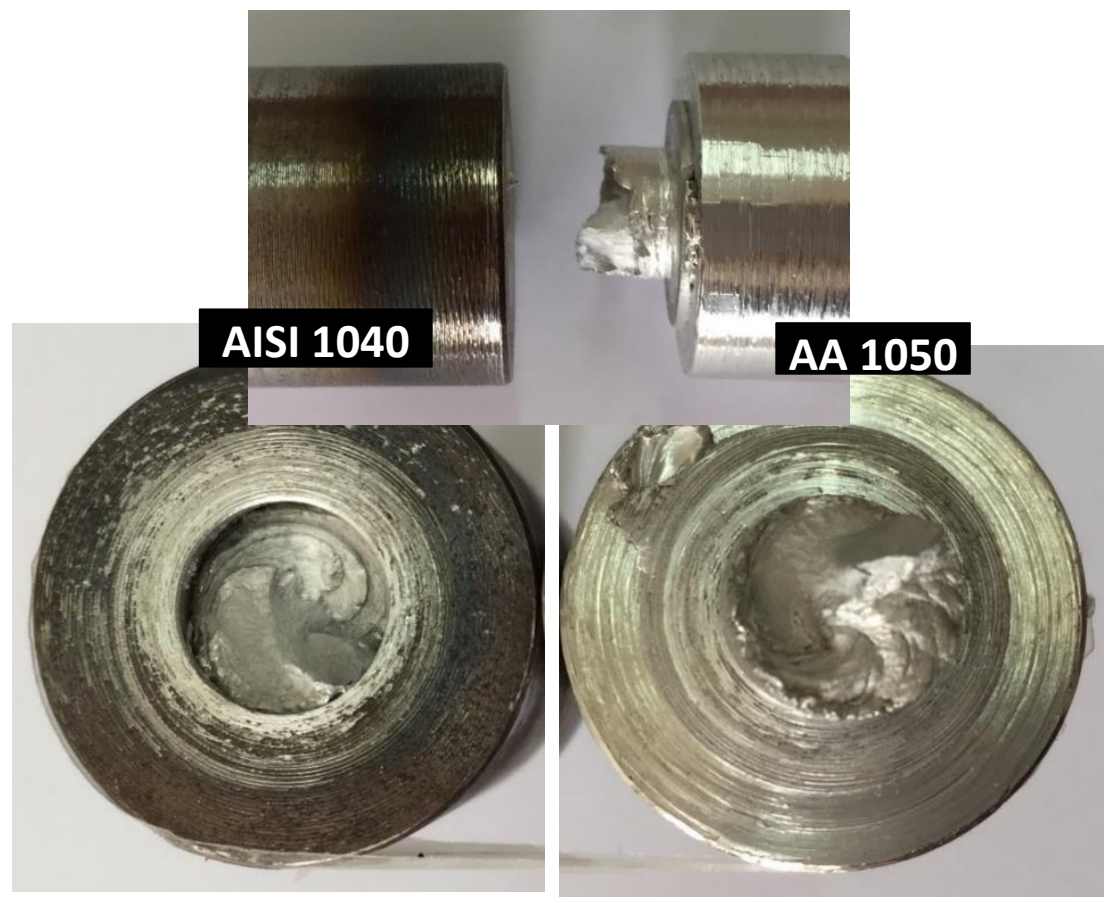

Şekil 12. Çekme deneyi sonucu kırllan numunelere ait makro görüntü

Kopmanın gerçekleştiği kesitin, ısı etkisinde kalan ve yüksek deformasyona uğrayan bölgeye yakın olduğu tespit edilmiştir. Bu durumun deformasyon bölgesinde oluşan mikro çatlaklar ve düzensiz deformasyona 
bağlı olarak meydana geldiği görülmüştür. Ayrıca yönlü olarak katılaşmış mikro yapının neden olduğu anizotropik davranışın kırılma üzerinde olumsuz olarak etkili olduğu düşünülmektedir [23].

Çekme deneyi sonucunda kırılan yüzeylere ait SEM görüntüleri Şekil 13' te gösterilmiştir. SEM görüntüleri incelendiğinde yüksek oranda bulunan çatlakların birleşerek kırılmaya neden olduğu tespit edilmiştir. Kırılmanın AA 1050 tarafında sünek kırılma olarak meydana geldiği görülmüştür.
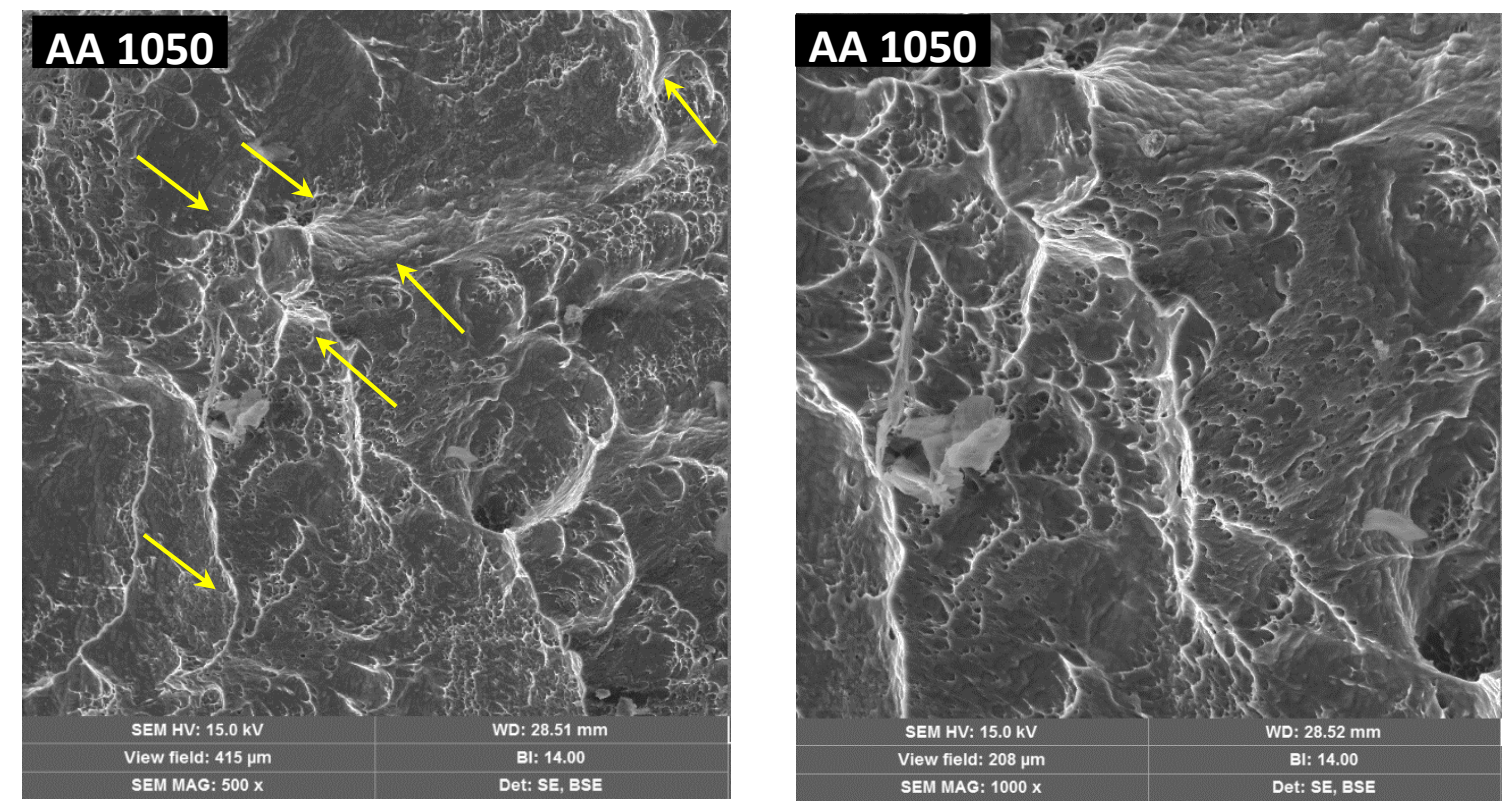

Şekil 13. Çekme deney sonucu kirılan numunelere ait SEM görüntüsü

\section{SONUÇ (CONCLUSUON)}

Mekanik kilitleme yöntemi kullanılarak AISI 1040 ve AA 1050 metal çiftleri başarılı bir şekilde birleştirilmiştir. Elde edilen sonuçlar ışığında mekanik kilitleme yönteminin diğer imalat yöntemleri ile birleştirilemeyen malzeme türlerinin birleştirilmesinde kullanılabileceği tespit edilmiştir. Böylece döküm ve kaynak yöntemi gibi diğer yöntemler ile birleştirilemeyen, kimyasal ve fiziksel özellikleri farklı olan malzeme türlerinin birleştirilmesinde yöntemin uygulanabileceği görülmüştür. Bu çalışma kapsamında malzemelerin birbirine sadece mekanik kilitlenme ile bağlandıkları, taneler arası difüzyon olmadığı ve bağlantı ara yüzeylerinde gözenekler meydana geldiği tespit edilmiştir. Bağlantı mukavemetini olumsuz etkileyen bu faktörlerin kullanılan parametrelerin optimizasyonu ile azaltılabileceği görülmüştür.

\section{KAYNAKLAR (REFERENCES)}

[1] https://www.hindawi.com/journals/jma/si/425934/cfp/ Erişim tarihi 13.05.2018.

[2] Mercan S., Özdemir N., (2013). AISI 2205 / AISI 1020 malzeme çiftinin sürtünme kaynağı ile birleştirilmesi, NWSA-Technological Applied Sciences, 8/2, 15-34.

[3] Liu G.L., Yang S.W., Han W.T., Zhoua L.J., Zhang M.Q., Ding J.W., Dong Y., Wan F.R., Shang C.J., Misra R.D.K., (2018). Microstructural evolution of dissimilar welded joints between reducedactivation ferritic-martensitic steel and 316L stainless steel during the post weld heat treatment, Materials Science \& Engineering A 722 182-196.

[4] Mercan S., (2017), Mekanik kilitleme yöntemi, Türk Patent ve Marka Kurumu, No: TR 201503256 B 2017/05/22.

[5] Çöl M., Yılmaz M., (2006). Yüksek frekanslı indüksiyon kaynağından sonra X52 mikroalyajlı çeliklerin 1sıl işlem parametrelerinin belirlenmesi, Malzeme ve Tasarım 27 507-512.

[6] Wang C., Luo T., Zhou J., Yang Y., (2018). Effects of solution and quenching treatment on the residual stress in extruded ZK60 magnesium alloy, Materials Science \& Engineering A 722 14-19.

[7] Robinson J.S., Redington W., (2015). The influence of alloy composition on residual stresses in heat treated aluminium alloys, Mater. Charact. 105 47-55. 
[8] Zheng L., Nie H., Zhang W., Liang W., Wang Y., (2018). Microstructural refinement and improvement of mechanical properties of hot-rolled $\mathrm{Mg}-3 \mathrm{Al}-\mathrm{Zn}$ alloy sheets subjected to pre-extrusion and $\mathrm{Al}-\mathrm{Si}$ alloying, Materials Science \& Engineering A 722 58-68.

[9] Xue Y., Wang X., Wang W., Zhong X., Han F., (2018). Compressive property of Al-based auxetic lattice structures fabricated by 3-D printing combined with investment casting, Materials Science \& Engineering A 722 255-262.

[10] Zhang K., Marthinsen K., Holmedal B., Aukrust T., Segatori A., (2018). Through thickness variations of deformation texture in round profile extrusions of 6063-type luminium alloy: Experiments, FEM and crystal plasticity modelling, Materials Science \& Engineering A 722 20-29.

[11] https://www.google.com.tr/url? sa=t\&rct=j\&q=\&esrc=s\&source=web\&cd=3\&cad=rja\&uact=8\&ved= 0ahUKEwjvhZOLienYAhVDECwKHXhQBuIQFgg2MAI\&url=http\%3A\%2F\%2Fakademi.itu.edu.tr\%2 Fatahanh\%2FDosyaGetir\%2F74205\%2Fch11_Termal\&usg=AOvVaw1ZpBm09PFACc3O7mGql_5z/ Erişim tarihi 21.01.2018.

[12] Acarer M., Demir H., (2008). An investigation of mechanical and metallurgical properties of explosive welded aluminum dual phase steel, Mater Letters, 62, 4158-4160.

[13] Erdem M., (2015). Investigation of structure and mechanical properties of copper-brass plates joined by friction stir welding, Internatioanl Journal Advanced Manufactoring Technology, 76: 1583-1592.

[14] Tunçay T., Özyürek D., (2014). Al-Si-Mg döküm alaşımlarında filtrasyonun mekanik özelliklere ve mikroyapıya etkisi, Gazi Üniversitesi Mühendislik Mimarlık Fakültesi Dergisi, 29: 2, 271-279.

[15] Kayıkc R., (2004). Use of computer modelling in predicting microporosity in a commerial aluminum casting, World Founder Congress, 66, İstanbul.

[16] Shabestari S. G., Shahri F., (2004). Influence of modification, solidification conditions and heat treatment on the microstructure and hechanical properties of A356 aluminum alloy, Kluwer Academic Publishers, 2023-12032.

[17] Balasubramanıan M., (2015). Development of processing windows for diffusion bonding of Ti-6Al-4V titanium alloy and 304 stainless steel with silver as intermediate layer. Transactions. Nonferrous Metals Society, China, 25, 2932-2938.

[18] Aydın M., (2008). Gözenekli seramik malzeme ile paslanmaz çeliğin difüzyon kaynak yöntemiyle birleştirilmesi, Gazi Üniversitesi Mühendislik Mimarlık Fakültesi Dergisi, 23:3, 595-599

[19] Atasoy E, Kahraman N., (2008). Diffusion bonding of commercially pure titanium to low carbon steel using a silver interlayer, Materials Characterization, 59, 1481-1490.

[20] Cheng X., Gao Y., FU H., Xing J., Bai B., (2010). Microstructural characterization and properties of $\mathrm{Al} / \mathrm{Cu} / \mathrm{steel}$ diffusion bonded joints, Metals and Materials International, 16:4, 649-655.

[21] Arık H., Semerci P., Kırmızı G., (2017). Sicak presleme ile alüminyum matrisli ve A12O3 takviyeli toz metal kompozit malzeme üretimi ve aşınma davranışının araştırılması, GU J Sci, Part C, 5(4): 87-97, Gazi Üniversitesi Fen Bilimleri Dergisi PART C: Tasarım ve Teknoloji.

[22] Meriç C., Köksal N.S., M. Erdoğan T., Okur A., (2008). Sürtünme kaynağı ile birleştirilmiş farklı malzemelerin kaynak bölgesinin incelenmesi, Celal Bayar Üniversitesi, Fen Bilimleri Dergisi, 4.2 135144, ISSN 1305-1385.

[23] Saarimäki J., Lundberg M., Brodin H., Moverare J.J., (2018). Dwell-fatigue crack propagation in additive manufactured Hastelloy X, Materials Science \& Engineering A 722, 30-36.

[24] Başak H., (2015). Haddeleme (Galetaj) ile 5083 Al-Mg malzeme yüzeyinin işlenmesi, haddeleme parametrelerinin yüzey pürüzlülüğ̈̈ ve yüzey sertliğine etkilerinin incelenmesi, GU J Sci, Part:C, 3(2): 471476, Gazi Üniversitesi Fen Bilimleri Dergisi PART:C, Tasarım Ve Teknoloji

[25] BAYAR H., SUBAŞI M., KARATAŞ Ç., (2015). 2SiC Takviyeli Alüminyum Alaşım Matrisli Kompozit Malzemenin Yüksek Basınçlı Kalıp Dökümü ve Mekanik Özellikleri, GU J Sci, Part, C, 3(4):603-612, Gazi Üniversitesi Fen Bilimleri Dergisi PART C: Tasarım ve Teknoloji. 